\title{
Some varied effects of punishment on ongoing avoidance behavior in the hamster
}

\author{
WILLIAM B. JANZEN, KATHARINA R. GEISSLER, and KENNETH B. MELVIN \\ University of Alabama, University, Alabama 35486
}

\begin{abstract}
Hamsters were trained to avoid shock by leaving a startbox and traversing a straight alley. During the first extinction phase (Phase I), one group was given 20 regular extinction (RE) trials, while a second group was given shock punishment $(\mathrm{PE})$ in the center of the alley. During the last 30 extinction trials (Phase II), conditions were reversed for the groups. Unlike earlier research with other species, punishment typically suppressed running, especially in the prepunishment area. However, a temporary punishment induced facilitation of alley speed was found.
\end{abstract}

Under certain conditions, punishment administered during the extinction of an aversively motivated running response may maintain or even enhance the punished response. As recent reviews of the literature reveal (Brown 1969; Melvin, 1971), the conditions leading to the development of this self-punitive or vicious circle behavior (VCB) have been well documented-at least so far as the laboratory rat is concerned. Although Martin, Ragland, and Melvin (1970) and Byrum and Melvin (1972) demonstrated the vicious circle effect with gerbils, certain performance differences between gerbils and rats were noted. For example, the gerbils tended to extinguish quickly during regular extinction (RE) conditions, presumably due to their strong, competing exploratory responses. Mice, however, yield data which are quite ratlike, exhibiting strong and stable self-punitive behavior in an avoidance situation (Brister $\&$ Melvin, in press). And recently, vicious circle behavior has been found with guinea pigs (Watkins, Reference Note 1).

The present experiment, which used hamsters as subjects, is the latest in a series of comparative studies of the self-punitive phenomenon. We employed a type of apparatus and "shift" design similar to that used by Melvin and Smith (1967) with rats, Byrum and Melvin (1972) with gerbils, and Brister and Melvin (in press) with mice. Although most earlier researchers had employed an extinction criterion of one to three $60-\mathrm{sec}$ trials, we ran a fixed number of extinction trials for each hamster in order to discern any recovery effects.

\section{METHOD}

\section{Subjects and Apparatus}

The subjects were 16 naive male outbred golden hamsters, 90-134 days old at the start of the experiment. They were obtained from Charles River, Inc., caged individually, and maintained on ad-lib food and water.

The apparatus has been described in detail by Melvin, Athey, and Heasley (1965). It consisted of a wide black wooden goalbox, a $30.5 \mathrm{~cm}$ startbox, and a $1.22 \mathrm{~m}$ straight alley. Both

We wish to thank Vanessa Searight and Mary Lee Kennedy for their able technical assistance. the alley and startbox had grid floors, glass lids, and were painted white. A trapdoor floor, hinged along one edge $15.2 \mathrm{~cm}$ above the grid floor, divided the startbox into upper and lower compartments. A barrier prevented the subject from leaving the upper compartment; a manually operated guillotine door at the entrance to the goalbox prevented retracing.

Photocells and associated electronic equipment recorded response times to $.01 \mathrm{sec}$. Prepunishment time was defined as the time elapsing from the release of the trapdoor until the subject had interrupted a light beam located $60.96 \mathrm{~cm}$ from the back wall of the startbox (just before the shock punishment zone). Alley time was taken as the time elapsing from the interruption of a light beam $31.75 \mathrm{~cm}$ from the back wall of the startbox to the interruption of a beam $1.27 \mathrm{~cm}$ inside the goalbox. Voltage was delivered through a $10 \mathrm{~K}$ ohm series resistor and monitored by a vacuum tube ac voltmeter. Shock intensity was $60 \mathrm{~V}$ ac on all shock trials.

\section{Procedure}

The hamsters were randomly assigned to one of two groups of eight subjects each.

Avoidance training. Prior to the experimental session, each subject was handled, placed in the startbox, and allowed to explore the startbox/alley and goalbox for $5 \mathrm{~min}$.

Following exploration, all subjects received identical avoidance training. The hamster was placed in the trapdoor compartment and, while facing the goalbox, dropped onto the grid floor. The release of the trapdoor was followed $5 \mathrm{sec}$ later by a $60-\mathrm{V}$ shock in the startbox and alley.

After the hamster entered the goalbox, the guillotine doors were lowered and the subject was allowed to remain in the goalbox for $30 \mathrm{sec}$. The acquisition criterion was five consecutive avoidances within 30 trials. All subjects met this criterion.

Extinction. Immediately following avoidance training, all subjects received two extinction phases; the first consisted of the first 20 extinction trials (Phase I). Group RE-PE received the RE condition in Phase I and the PE condition in Phase II, which included Trials 21-50. Group PE-RE was given PE in Phase I and $\mathrm{RE}$ in Phase II. During RE (regular extinction), no shock was ever present in any part of the apparatus. During PE (punishment extinction), shock was present in the middle $60.96 \mathrm{~cm}$ of the alley on each trial. If the animal did not enter the goalbox within $60 \mathrm{sec}$, it was placed in the goalbox for $30 \mathrm{sec}$, and a time of $60 \mathrm{sec}$ was recorded. No extinction criterion was used, i.e., all hamsters received all 50 trials. 


\section{RESULTS}

All subjects learned the avoidance response. A t test of the two group means on alley speed on the last training trial was not significant $(\mathrm{t}<1)$.

\section{Prepunishment Speed}

Figure 1 represents mean speeds $(1 /$ time $)$ in the startbox and alley sections preceding the electrified grid for the two groups across five-trial blocks.

Phase I. Analysis of variance across the four blocks of trials constituting Phase I revealed a significant groups effect $(F=15.16, \mathrm{df}=1 / 14, \mathrm{p}<.001)$ and blocks effect $(\mathrm{F}=11.58, \mathrm{df}=3.42, \mathrm{p}<.01)$. Animals in the PE-RE groups showed marked suppression with punishment. Performance of RE-PE hamsters also declined; however, they ran significantly faster than the punished group.

Phase II. Analysis of variance over the six blocks of trials of Phase II revealed that the blocks effect, as well as the interaction effect $(F=6.07, d f=5 / 70, p<.001)$, were significant. Again, punishment did not facilitate running (see Figure 1). The deletion of punishment for Group PE-RE led to temporary recovery of running as indicated by the curvilinear relationship depicted in Figure 1, Phase II.

\section{Alley Speed}

Mean alley speed for the two groups over five-trial blocks is shown in Figure 2.

Phase I. A 2 by 4 analysis of variance of alley speeds showed significant effects for blocks and the interaction effect $(\mathrm{F}=3.06, \quad \mathrm{df}=3 / 42, \mathrm{p}<.05)$. As Figure 2 indicates, punishment has a facilitative effect on speed during Block $1(t=3.66, p<.01)$ but the decline in performance is steeper for these punished animals (Group PE-RE) than for the nonpunished subjects of Group RE-PE. By the end of Phase I, eight PE-RE

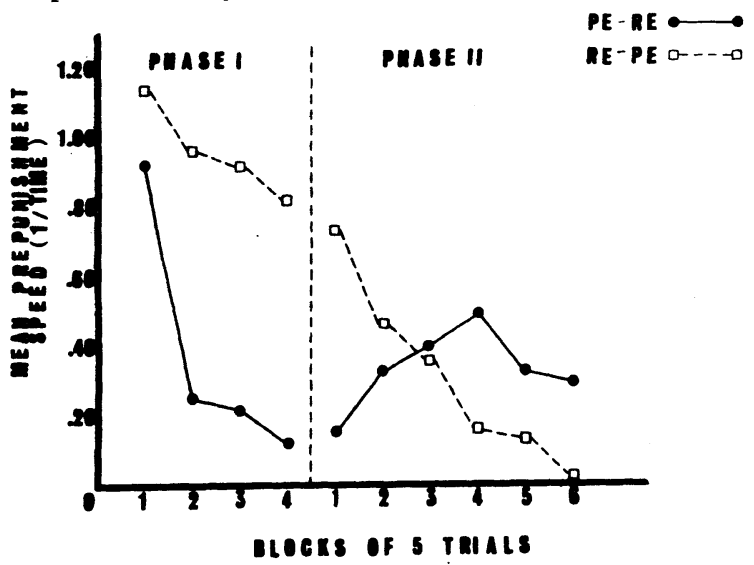

Figure 1. Mean prepunishment speed for two groups of hamsters on successive blocks of five trials during two phases of extinction. Group RE-PE received regular extinction followed by punishment extinction. Group PE-RE received these conditions in reverse order.

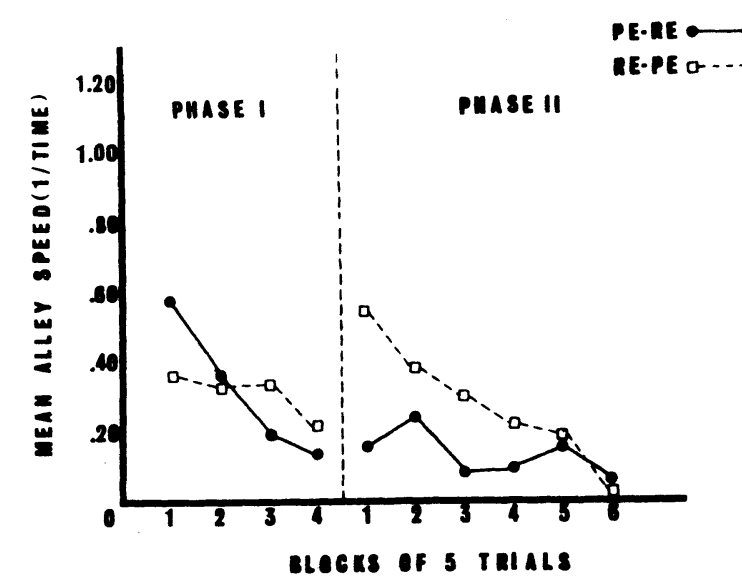

Figure 2. Mean alley speed for two groups of hamsters on successive blocks of five trials during two phases of extinction.

animals had shown marked suppression, i.e., alley time of at least $60 \mathrm{sec}$, whereas only two of the nonpunished (RE-PE) hamsters slowed to this extent.

Phase II. Analysis of variance for the two groups over six blocks of trials revealed significant effects of blocks and the Groups by Blocks interaction $(F=4.99$, $\mathrm{df}=5.70, \mathrm{p}<.001)$. Group PE-RE seems to show a slight recovery effect from the suppression evident in Phase I. Punishment initially (Block 1, Phase II) facilitated alley speed for Group RE-PE relative to the last block of Phase $I(t=3.80, p<.01)$, during which these hamsters were not punished. As Figure 2 indicates, Group RE-PE gradually suppressed the running behavior over the next five blocks of trials.

\section{DISCUSSION}

Although conditions were comparable to those of prior research, little evidence of self-punitive behavior was exhibited by hamsters. The vicious-circle effect had been found in both rats (c.f., Melvin \& Smith, 1967), mice (Brister \& Melvin, in press), and guinea pigs (Watkins, Reference Note 1). In fact, with the identical apparatus and a design similar to ours, gerbils exhibited strong and stable self-punitive running (Byrum \& Melvin, 1972).

Temporary punishment-induced facilitation was seen in alley speed. During the first block of trials, the punished (PE-RE) group ran faster than the control group; however, there was no significant difference in running speed thereafter. Punishment also led to increased speed when Group RE-PE was shifted to the $\mathrm{PE}$ condition. Again, suppression followed this temporary facilitation.

On the prepunishment measure, the results indicated punishment-induced suppression during Phase I. When punishment was deleted (Phase II), the suppressed PE-RE group then showed recovery of the avoidance response. This suggests that, when animal behavior is suppressed in the vicious-circle paradigm, the conditioned fear of the prepunishment area established during avoidance training is still present. However, fear of punishment shock in the middle section is strong enough to prevent running. This analysis is supported by observations of hamsters which, after suppression of running, attempted to climb out of the startbox.

When the hamsters in Group PE-RE experienced no shock 
punishment in Phase II, fear of the middle section declined to the point where subjects left the startbox and ran to the goalbox. However, some residual conditioned fear of the middle of the alley remained, temporarily increasing alley speed. Subsequent lack of punishment in the center of the alley resulted in the extinction of running behavior.

Why do hamsters, under optimal conditions for other rodents, fail to exhibit vicious-circle behavior? One possibility might be that the alley, designed for rats, is simply too large. However, Byrum and Melvin (1972) established the phenomenon in gerbils, a species of similar size. A second possibility may relate to the type of startbox used-one containing a trapdoor. In hamsters, the drop appeared to elicit a startle response which competed with running. Even though the trapdoor technique may be more effective in the vicious-circle paradigm with rats (cf. Delprato \& Meltzer, 1974), a guillotine door arrangement might work better with hamsters.

\section{REFERENCE NOTE}

Watkins, K. L. Self-punitive behavior in the Cavia porcellus. Paper presented at the meeting of the Southeastern Psychological Association, New Orleans, 1973.

\section{REFERENCES}

Brister, P.D., \& Melvin, K. B. Self-punitive avoidance behavior in the mouse. Animal Learning \& Behavior, in press.

Brown, J. S. Factors affecting self-punitive locomotor behavior. In B. A. Campbell \& R. M. Church (Eds.), Punishment and aversive behavior. New York: Appleton-Century-Crofts, 1969, Pp. 467-514.

Byrum, R. P., \& Melvin, K. B. Self-punitive avoidance behavior in the Mongolian gerbil. Psychonomic Science, 1972, 28, 13-15.

Delprato, D. J., \& Meltzer, R. J. Type of start box and goal box distinctiveness in self-punitive running of rats. Journal of Comparative and Physiological Psychology, 1974, 87, 548-554.

Martin, R. C., Ragland, E., \& Melvin, K. B. Self-punitive locomotor behavior in the Mongolian gerbil. Psychonomic Science, 1970, 20, 183-184.

Melvin, K. B. Vicious circle behavior. In H. D. Kimmel (Ed.), Experimental psychopathology: Recent research and theory. New York: Academic Press, 1971, Pp. 95-115.

Melvin, K. B., Athey, G. I. Jr., \& Heasley, F. H. Effects of duration and delay of shock on self-punitive behavior in the rat. Psychological Reports, 1965, 17, 107-112.

Melvin, K. B., \& Smith, F. H. Self-punitive avoidance behavior in the rat. Journal of Comparative and Phy siological Psychology, $1967,63,533-535$.

(Received for publication May 14, 1975.) 